\title{
KAJIAN KUALITAS HIDUP PASIEN YANG MENJALANI HEMODIALISA DI RSUD. A.W. SJAHRANIE
}

\author{
Firmansyah $^{1, \dagger}$, Jaka Fadraersada ${ }^{1,2}$, Rolan Rusli ${ }^{1,3, \sharp}$ \\ ${ }^{1}$ Laboratorium Penelitian dan Pengembangan Kefarmasian "Farmaka Tropis", \\ Fakultas Farmasi, Universitas Mulawarman, Samarinda, Indonesia \\ †Email: syah28firman@gmail.com \\ ${ }^{2}$ Kelompok Keilmuan Farmasi Klinik \& Komunitas, Fakultas Farmasi, \\ Universitas Mulawarman, Samarinda, Kalimantan Timur \\ ${ }^{3}$ Kelompok Bidang Ilmu Kimia Farmasi, Fakultas Farmasi, \\ Universitas Mulawarman, Samarinda, Indonesia \\ *Email: rolan@farmasi.unmul.ac.id
}

\begin{abstract}
ABSTRAK
Gagal ginjal kronik merupakan suatu keadaan yang ditandai dengan kelainan struktur atau fungsi ginjal dengan ekskresi albumin abnormal atau penurunan fungsi ginjal yang dilihat dengan pemeriksaan laju filtrasi glomerulus (LFG) yang berlangsung selama lebih dari 3 bulan. Pada pasien dengan LFG kurang dari $15 \mathrm{ml} / \mathrm{menit}$ dilakukan terapi pengganti ginjal seperti hemodialisis, yang dilakukan tiap 3 hingga 4 kali seminggu, sehingga perlu diteliti mengenai kualitas hidup pasien gagal ginjal kronik yang menjalani hemodialisis. Tujuan penelitian ini yaitu untuk mengetahui karakteristik dan gambaran kualitas hidup pasien gagal ginjal kronik yang menjalani hemodialisis. Metode penelitian yang digunakan yaitu metode observasional dengan penelusuran data secara prospektif dan menggunakan data rekam medik serta data hasil wawancara dengan pasien menggunakan kuesioner KDQOL-SF di Rumah Sakit Umum Daerah Abdul Wahab Sjahranie Samarinda. Pasien gagal ginjal kronik yang menjalani hemodialisis di RSUD A.W Sjahranie memiliki kualitas hidup dalam kategori baik sebanyak 47,6\%, kategori cukup sebanyak 23,8\% dan 28,6\% memiliki kualitas hidup dalam kategori kurang.
\end{abstract}

Kata Kunci: gagal ginjal kronik, hemodialisis, kualitas hidup, laju filtrasi glomerulus, kdqol-sf

DOI: https://doi.org/10.25026/mpc.v7i1.292

PENDAHULUAN

besar di dunia. Selain sulit disembuhkan, biaya perawatan dan pengobatannya pun sangat mahal [3,9]. Berdasarkan Global Burden of Disease Study tahun 2010, GGK berada di posisi 27 sebagai penyebab kematian global
(15,7 dari 100.000 kematian/tahun pada tahun 1990) dan berada di posisi 18 sebagai penyebab kematian (16,3 dari 100.000 kematian/tahun pada tahun 2010) [6]. Menurut data Persatuan Nefrologi Indonesia (Pernefri) diperkirakan terdapat 70.000 penderita gagal ginjal di Indonesia yang akan 
terus meningkat sekitar $10 \%$ setiap tahun [11]. Prevalensi GGK di Indonesia menurut Riskesdas tahun 2013 adalah $0,2 \%$ [5].

Kualitas hidup pasien seharusnya menjadi perhatian penting bagi para professional kesehatan karena dapat menjadi acuan keberhasilan dari suatu tindakan/intervensi atau terapi. Di samping itu, data tentang kualitas hidup juga dapat merupakan data awal untuk pertimbangan merumuskan intervesi/tindakan yang tepat bagi pasien [8].

Hemodialisa (HD) adalah suatu prosedur dimana darah dikeluarkan dari tubuh penderita dan beredar dalam sebuah mesin di luar tubuh yang disebut dialiser. Frekuensi tindakan HD bervariasi tergantung banyaknya fungsi ginjal yang tersisa, rata-rata penderita menjalani tiga kali dalam seminggu, sedangkan lama pelaksanaan hemodialisa paling sedikit tiga sampai empat jam tiap sekali tindakan te-rapi $[2,12]$.

Proses hemodialisa membutuhkan waktu selama $4-5$ jam umumnya akan menimbulkan stress fisik, pasien akan merasakan kelelahan, sakit kepala, dan keluar keringat dingin akibat tekanan darah yang menurun [4,7]. Terapi HD juga akan mempengaruhi keadaan psikologis pasien. Pasien akan mengalami gangguan proses berpikir dan konsentrasi serta gangguan dalam berhubungan sosial. Semua kondisi tersebut akan menyebabkan menurunnya kualitas hidup pasien GGK yang menjalani terapi HD. Kualitas hidup pasien GGK yang menjalani terapi HD sangat dipengaruhi oleh beberapa masalah yang terjadi sebagai dampak dari terapi HD dan juga dipengaruhi oleh gaya hidup pasien [10].

Keperawatan sebagai suatu profesi kesehatan yang paling lama berinteraksi dengan pasien, sangat berperan dalam membantu pasien meningkatkan daya adaptasi terhadap perubahan yang dialami serta mengelola permasalahan yang muncul agar pasien tetap bertahan hidup dan sehat. Melalui pendekatan metodologi asuhan keperawatan, perawat melakukan pengkajian, merumuskan diagnosis perawatan, menyusun rencana tindakan/intervensi, melaksanakan dan mengevaluasi hasil asuhan perawatan. Data tentang kualitas hidup pasien sangat diperlukan sebagai bahan masukan untuk merumuskan intervensi yang tepat dan sekaligus sebagai alat ukur untuk menilai hasil asuhan keperawatan yang diberikan [1].

\section{METODE PENELITIAN}

\section{Pencatatan Data Rekam Medik dan Data Wawancara}

Dilakukan pencacatan dan dokumentasi data rekam medik pasien gagal ginjal kronik untuk mengetahui data karakteristik pasien gagal ginjal kronik dan dilakukan wawancara dengan menggunakan kuesioner KDQOL-SF untuk mendapatkan data kualitas hidup pasien gagal ginjal kronik yang menjalani hemodialisis.

\section{Analisis Karakteristik}

Dianalisis karakteristik pasien (usia, jenis kelamin, pekerjaan, tingkat pendidikan, suku, dan lama menjalani hemodialisis), dengan diolah secara manual yang kemudian dianalisis berupa tabulasi dan persentase.

\section{Analisis Gambaran Kulitas Hidup}

Dianalisis dengan melakukan wawancara ke pasien menggunakan kuesioner KDQOL-SF yang kemudian diolah secara manual dengan proses editing dan menghitung nilai skoring dari kuesioner KDQOL-SF. 
HASIL DAN PEMBAHASAN

\section{Karakteristik Pasien gagal Ginjal Kronik}

Pasien Gagal ginjal kronik yang menjadi sampel dalam penelitian ini adalah sebanyak 21 sampel. Kemudian di karakterisasi berdasarkan usia, jenis kelamin, suku, pekerjaan, tingkat pendidikan, dan lama menjalani hemodialisis. Karakteristik pasien berdasarkan usia 25-45 tahun sebanyak 14 pasien, usia 46-65 tahun sebanyak 7 pasien.

Berdasarkan tabel 1 sebagian besar pasien gagal ginjal kronik berusia antara 25 hingga 45 tahun hal ini tidak berbeda dengan penelitian yang dilakukan di unit hemodialisa RSPAD Gatot Soebroto yang menyatakan bahwa responden yang menderita gagal ginjal kronik banyak pada kelompok usia produktif yaitu berjumlah $71,7 \%$. Kecederungan bertambahnya penderita gagal ginjal kronik dan bergesernya usia responden 10 tahun lebih muda dari 3040 tahun terjadi dikarenakan gagalnya pencegahan primer seperti menghindari faktor resiko, sehingga hal ini dapat menyebabkan timbulnya penyakitpenyakit seperti diabetes mellitus dan hipertensi, dan salah satunya pencegahan primer yang dilakukan yaitu dengan menghindari kebiasaan merokok karena kebiasaan merokok tersebut dapat memperbesar resiko terjadinya penyakit yang berhubungan dengan terjadinya penyempitan pada pembuluh darah, termasuk pembuluh darah diginjal, serta angka kejadian penyakit seperti diabetes mellitus dan hipertensi juga meningkat kejadiannya pada usia produktif. Hal itulah yang menjadi alasan banyaknya pasien usia produktif yang mengidap gagal ginjal kronik.

Karakteristik pasien gagal ginjal

kronik berdasarkan jenis kelamin banyak diderita oleh pasien laki-laki yaitu sebanyak 57\%. Hal ini sesuai dengan data dari USRDS bahwa pasien gagal ginjal kronik terbanyak adalah laki-laki. Hal ini berhubungan dengan faktor resiko yang bersifat multifaktorial yaitu pekerjaan yang berhubungan dengan bahan-bahan kimia yang apabila terpapar dan masuk kedalam tubuh akan dapat mempengaruhi ginjal. Selanjutnya yaitu gaya hidup yang tidak sehat misalnya kebiasaan merokok serta meminum minuman yang beralkohol dapat menimbulkan penyakit gagal ginjal kronik. Terdapatnya kecenderungan laki-laki lebih rentan terkena gagal ginjal kronik dikarena faktor pekerjaan pada laki-laki lebih berat baik dari segi fisik maupun beban mental yang dialaminya dari pada perempuan dan faktor kebiasaan merokok lebih tinggi terjadi pada lakilaki dibandingkan perempuan.

Bedasarkan tabel 1 didapatkan hasil pasien terbanyak memiliki tingkat pendidikan terakhirnya yaitu perguruan tinggi sebanyak $42.9 \%$. Hal ini sama dengan penelitian yang dilakukan oleh Batubara yang menunjukkan jumlah respondennya mayoritas adalah pendidikan terakhirnya perguruan tinggi. Status pendidikan terakhir berperan penting dalam menentukan status kesehatan dan kualitas hidup seseorang, semakin tinggi tingkat pendidikan seseorang maka kesadaran tentang pentingnnya kesehatan dan pengobatan akan masalah kesehatannya yang dihadapinya juga akan semakin tinggi dan akan cenderung berfikir lebih positif. Status pendidikan terakhir juga berpengaruh terhadap sumber daya ekonomi dan sosial yang dicapai, sehingga muncul paradigma bahwa tingkat pendidikan yang rendah mengakibatkan suatu individu memiliki pengetahuan yang rendah terhadap kesehatan dirinya dan dapat jatuh pada keadaan stressfull, sehingga hal ini dapat menyebabkan meningatnya resiko gagal ginjal kronik. 
Tabel 1. Karakteristik pasien berdasarkan usia

\begin{tabular}{|c|c|c|}
\hline Karakteristik Pasien & Jumlah (pasien) & Persentase (\%) \\
\hline \multicolumn{3}{|l|}{ Usia } \\
\hline $25-45$ tahun & 14 & 67 \\
\hline 46-65 tahun & 7 & 33 \\
\hline \multicolumn{3}{|l|}{ Jenis Kelamin } \\
\hline Laki-Laki & 12 & 57 \\
\hline Perempuan & 9 & 43 \\
\hline \multicolumn{3}{|l|}{ Tingkat Pendidikan } \\
\hline Tidak Sekolah & 1 & 4,8 \\
\hline Pendidikan dasar & 4 & 19 \\
\hline Pendidikan Menengah & 7 & 33,3 \\
\hline Pendidikan tinggi & 9 & 42,9 \\
\hline \multicolumn{3}{|l|}{ Pekerjaan } \\
\hline Tidak bekerja & 9 & 42,9 \\
\hline Karyawan & 7 & 33,3 \\
\hline Wiraswasta & 4 & 19 \\
\hline PNS & 1 & 4,8 \\
\hline \multicolumn{3}{|l|}{ Suku } \\
\hline Jawa & 13 & 61,9 \\
\hline Banjar & 2 & 9,5 \\
\hline Bugis & 3 & 14,3 \\
\hline Kutai & 2 & 9,5 \\
\hline Dayak & 1 & 4,8 \\
\hline \multicolumn{3}{|l|}{ Lama menjalani hemodialisis } \\
\hline$\leq 1$ tahun & 8 & 38,1 \\
\hline$\overline{1}-5$ tahun & 10 & 47,6 \\
\hline$\geq 5$ tahun & 3 & 14,3 \\
\hline
\end{tabular}

Berdasarkan tabel 1 didapatkan mayoritas pasien bekerja sebagai IRT, pensiun dan tidak bekerja (42,9\%). Berdasarkan penelitian yang dilakukan oleh Asri dkk menyatakan 2/3 pasien yang menjalani dialisis tidak pernah dapat kembali pada aktivitas atau pekerjaan semula sehingga pasien dapat kehilangan pekerjaannya. Rendahnya aktivitas seseorang dapat berpengaruh terhadap perburukan kesehatan baik dari segi fisik maupun psikis individu, sehingga dapat mengakibatkan seseorang sakit.

Berdasarkan tabel 1 responden penelitian terbanyak berasal dari suku jawa (61.9\%). Pentingnya melihat suku atau budaya pada penelitian ini dikarenakan hal tersebut dapat mengakibatkan perbedaan interpretasi terkait dengan pandangan mengenai hidup sehat, menangani keluhan yang muncul, dan cara mengobati atau mencari pertolongan serta merawat orang sakit. Perbedaan suku juga dapat mempengaruhi seseorang dalam mengambil sebuah keputusan tentang penggunaan layanan kesehatan. Hal ini juga dapat berlaku untuk pasien yang mengalami gagal ginjal, misalnya dalam menentukan jenis dialisis yang akan mereka jalani, memilih akses vaskuler, mendukung anggota keluarga dalam melaksanakan HD, dan memberikan motivasi untuk mematuhi jumlah asupan cairan dan protein yang akan berdampak 
terhadap kualitas hidup pasien gagal ginjal.

Pada tabel 1 didapatkan hasil bahwa mayoritas pasien menjalani hemodialisis dengan kurun waktu 1-5 tahun sebanyak $47.6 \%$. pasien yang menjalani hemodialisis $<1$ tahun biasanya sering mengalami komplikasi seperti hipoalbumin, peritonitis, infeksi exit site/tunnel dan kebocoran cairan dialisat. Sedangkan responden yang menjalani hemodialisis $>5$ tahun, jarang kontrol ke tenaga medis dan banyak responden telah lupa prosedur standar perawatan hemodialisis.

Tabel 2. Gambaran kualitas hidup pasien gagal ginjal kronik yang menjalani hemodialisis.

\begin{tabular}{ccc}
\hline $\begin{array}{c}\text { Kualitas } \\
\text { Hidup }\end{array}$ & $\begin{array}{c}\text { Jumlah } \\
\text { (pasien) }\end{array}$ & $\begin{array}{c}\text { Persentase } \\
(\%)\end{array}$ \\
\hline Baik & 10 & 47,6 \\
Cukup & 5 & 23,8 \\
Kurang & 6 & 28,6 \\
\hline
\end{tabular}

Pada penelitian ini dengan menggunakan kuesioner KDQOL-SF didapatkan sebanyak $47,6 \%$ pasien gagal ginjal kronik yang menjalani hemodialisis memiliki kualitas hidup yang baik, 23,8\% memiliki kualitas hidup cukup dan $24 \%$ termasuk dalam kategori kurang (Tabel 2). Kualitas hidup pasien gagal ginjal kronik merupakan salah satu hal yang penting untuk menilai efek samping dari sebuah terapi pengobatan. Kualitas hidup dapat menggambarkan suatu beban seorang penderita akibat penyakit yang dideritanya dan terapi yang diperolehnya. Berdasarkan data pada Tabel 2 dapat dinyatakan bahwa Hemodialisis belum signifikan mengurangi kualitas hidup pasien karena adanya dukungan keluarga dalam menjalani hidup selama proses hemodialisis.

\section{KESIMPULAN}

Berdasarkan penelitian yang telah dilakukan maka dapat disimpulkan bahwa karakteristik pasien gagal ginjal kronik paling banyak diderita oleh lakilaki sebanyak $57 \%$ dengan usia antara 25 hingga 45 tahun, memiliki tingkat pendidikan dan pengetahuan yang tinggi, mayoritas bersuku jawa dan lama pasien menjalani hemodialisis dengan rentan 1-5 tahun.

Pasien gagal ginjal kronik yang menjalani hemodialisis di RSUD A.W Sjahranie memiliki kualitas hidup dalam kategori baik sebanyak 47,6\%, 23,8\% memiliki kualitas hidup cukup dan $24 \%$ termasuk dalam kategori kurang.

\section{DAFTAR PUSTAKA}

[1] Anderson, M.P. 1999. Stress Management for Chronic Disease. New York: Pergamon Press.

[2] Brunner \& Suddarth. 2002. Buku Ajar Keperawatan Medikal Bedah, Ed 8. Jakarta: EGC.

[3] Chen, S.C., Chang, J.M., Hwang, S.J., Chen, J.H., Lin, F.H., Su, H.O. and Chen, H.C. 2009. Comparison of Ankle-Brachial Index and BrachialAnkle Pulse Wave Velocity between Patients with Chronic Kidney Disease and Hemodialysis. Am J Nephrol, 29: 374-380.

[4] Gallieni, M., Butti, A., Guazzi, M., Galassi, A., Cozzolino, M. and Brancaccio, D. 2008. Impaired Brachial Artery Endothelial FlowMediated Dilation and Orthostatic Stress in Hemodialysis Patients. " e International Journal of Arti! cial Organs, 31(1): 34-42.

[5] Kemenkes RI. Riset kesehatan dasar (Riskesdas) 2013. Jakarta: Kemenkes RI; 2013.

[6] Lozano R, Naghavi M, Foreman K, Lim S, Shibuya K, Aboyans V, et al. Global and regional mortality from 
235 causes of death for 20 age groups in 1990 and 2010: a systematic analysis for the Global Burden of Disease Study 2010. Lancet. 2012;380(9859):2095- 128.

[7] Orlic, L., Crncevic, Z., Pavlovic, D. and Zaputovic, L. 2010. Bone Mineral Densitometry in Patients On Hemodialysis: Di\# erence Between Genders and What to Measure Bone Mineral Density in Hemodialysis Patients. Renal Failure, 32: 300-308.

[8] Post, J.B., Jegede, A.B., Morin, K., Spungen, A.M., Langho\# , E. and Sano, M. 2010. Cognitive Pro\$ le of Chronic Kidney Disease and Hemodialysis Patients without Dementia. Nephron Clin Pract, 116: c247-c255.
[9] Russell, M.R., Gómez, L.L.T., Domínguez, R.L.P., Santiago, R.E. and Cervantes, M.L. 2011. Work Climate in Mexican Heamodialysis Units: A Cross-Sectional Study. Nefrologia, 31 (1): 76-83.

[10] Suhud, M. 2005. Cuci Darah Demi Kualitas Hidup, Kompas Syb.

[11] Suwitra K. Penyakit ginjal kronik. Dalam: Sudoyo A, editor. Buku Ajar Ilmu Penyakit Dalam. Jakarta: Pusat Penerbitan IPD FKUI; 2007. p. 5702.

[12] Yang, L., Lin, Y., Ye, C., Mao, Z., Rong, S., Zhao, X. and Mei, C. 2011. E\# ects of Peritoneal Dialysis and Hemodialysis on Arterial Sti\# ness Compared with Predialysis Patients. Clinical Nephrology, 75 (3): 188194. 